\title{
THE DEMOGRAPHIC POTENTIAL OF RURAL SETTLEMENTS IN THE METROPOLITAN AREA OF SUCEAVA: ADVANTAGES AND RESTRICTIONS IN THE DEVELOPMENT PROCESS
}

DOI: http://dx.doi.org/10.18509/GBP.2020.91

UDC: 911.373:314(498)

\author{
Vasile Efros \\ Nicoleta Morar \\ "Ștefan cel Mare" University of Suceava, Romania
}

\begin{abstract}
The identification of the current demographic characteristics of the rural settlements in the Metropolitan Area of Suceava and indicating the favorable elements as well as the vicissitudes existing at the level of the dynamic component of the territorial system represents an indispensable step in the elaboration of a sustainable development strategy. This aspect can only be accomplished from the point of view of the temporal evolution of the most important indicators reflecting the quantitative and qualitative features of the population, such as the inhabitants number evolution, the rate of the natural and migratory balance, the population structure by age and sex groups, the confessional and ethnical structure, occupational structure and the population education level. Therefore, in signaling the specificities existing at the level of the demographic component, it was considered effective to analyze the indicators based on the data of the last two surveys, but also based on the last years that offer the newest information regarding the mentioned elements.
\end{abstract}

Keywords: development, demography, development strategy, rural settlements

\section{INTRODUCTION}

The population is the dynamic factor that contributes decisively to achieving social economic objectives within a territorial system. The territorial assembly represented by the metropolitan area is subject to the elements and connections between its elements, which must aim to achieve common objectives optimally. The metropolitan area is a voluntary, administrative partnership-based association structure that includes a city and its surrounding areas, including multiple economic, social, educational or administrative conjuncture relationships. We believe that a metropolitan area must be characterized by coherence and synergy. According to Ianoș, "coherence shows the close link between each natural or social component between component sets", and the synergy "stems from "their cooperation, in order to give the ensemble a function"[2]. From a constituent point of view, the metropolitan area represents "an intercommoned cooperation structure resulting from the complementarity of the potential of the two types of administrative structures at a local level: those with advanced urbanization, represented by the regional and departmental convergence nuclei and the municipalities included in their peri-urban area. [3].

The importance of the population derives from its triple hypostasis: the main component of the space, an essential factor in the development and implementation of development programs and the beneficiary of the achievements and results obtained [1]. 
The Metropolitan Area of Suceava (figure 1) is an association of territorial administrative units established in 2014, which includes the cities of Suceava, urban settlement type II and Salcea, which belongs to the category of urban centers with specialized functions, declared in 2004, according to law 83, of 2004, regarding the change into towns of some villages [4]. and Adâncata, Bosanci, Dumbrăveni, Hânţeşti, Mitocu Dragomirnei, Moara, Pătrăuţi, Siminicea, Stroieşti, Udeşti, Vereşti. From a demographic point of view, the metropolitan area of Suceava is defined by a total of 201,868 inhabitants, of which $35.6 \%$ represents the rural population.

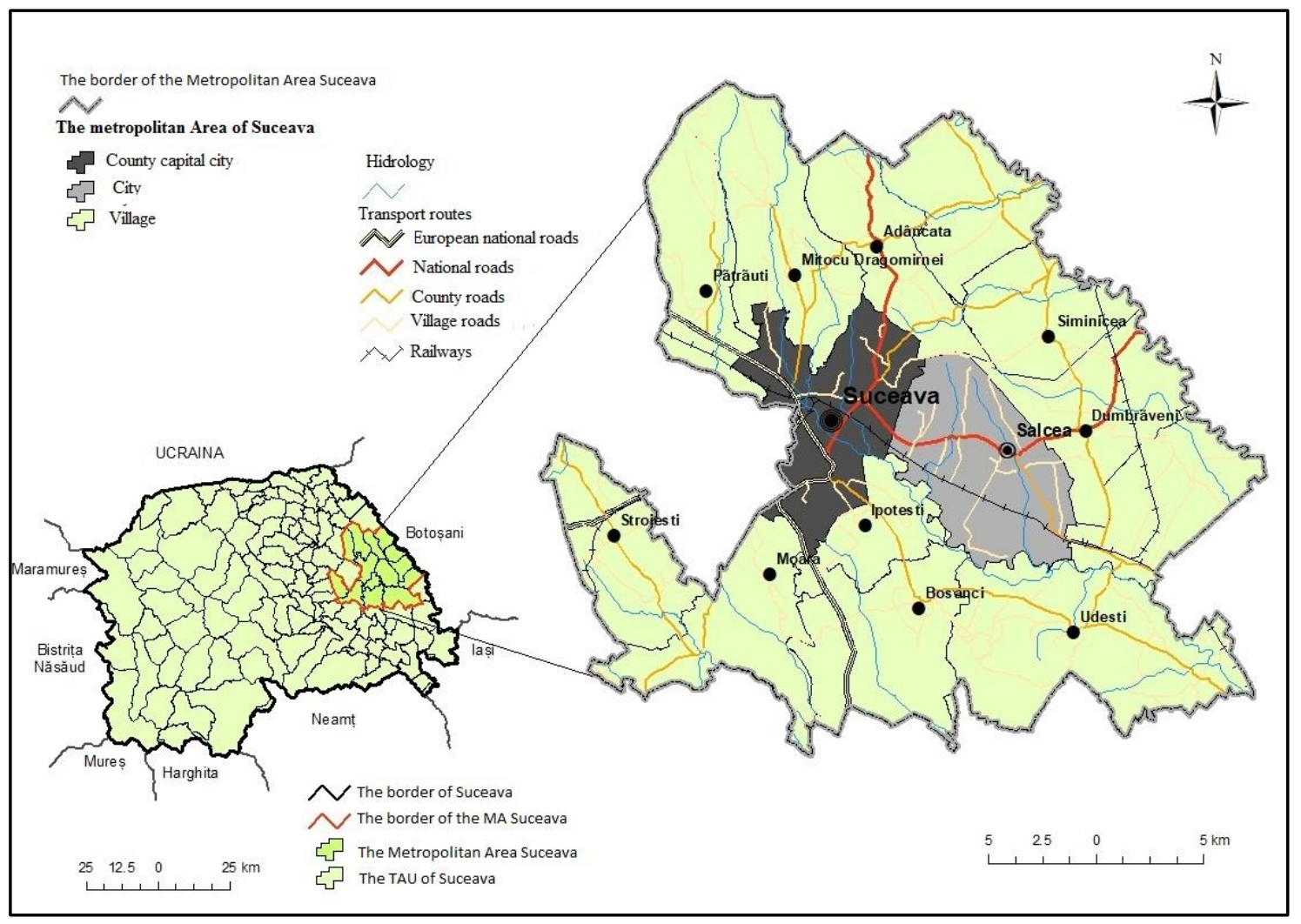

Figure 12. Study area

This study aims to highlight the main demographic characteristics of rural settlements in the metropolitan area of Suceava, which can contribute to its integrated development or which may make it difficult for the process to function or evolve optimally.

\section{METHODOLOGY}

For the analysis of the demographic potential of rural settlements in the metropolitan area of Suceava, the statistical data provided by the National Statistical Institute will be analyzed on the tempo - online platform [5], which captures the current attributes of the population. Data processing was conceded in Excel 2016, and cartographic materials were carried out through ArcGis 10.1 (figure 2). 
The evolution of inhabitants number Population dynamic

The age structure of population

The ethnic and religious share of poplation

The occupational structure of population and the unemployment rate

The educational structure of population

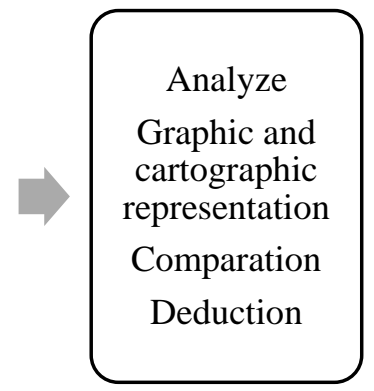

\section{Analyze}

Graphic and cartographic representation Comparation Deduction
The demographic potential of rural settlements in the Metropolitan Area of Suceava

Figure 2. Methodology scheme

\section{RESULTS}

The numerical evolution of the rural population in the metropolitan area of Suceava (figure 3) had an upward direction, with the largest increase in 2019. The population growth in the range considered was $21 \%$. At the level of territorial administrative units, it can be seen that there are villages that have seen population declines, others with increases in the number of inhabitants, which exceeded 50\% in 2017, compared to 2000. Thus, following the calculation of the population growth rate, which was carried out on the basis of data on the inhabitants' number in 2000 and 2019, five categories of villages were individualized:

- with a decrease in population growth rate $(<0 \%)$

- with a very small increase in the population growth rate $(0.1-10 \%)$

- with a small increase in population growth rate (10.1-20\%)

- with an average increase in population growth rate (20.1-30\%)

- with a large increase in population growth rate (30.1-40\%)

- with a very large increase in population growth (>40\%)
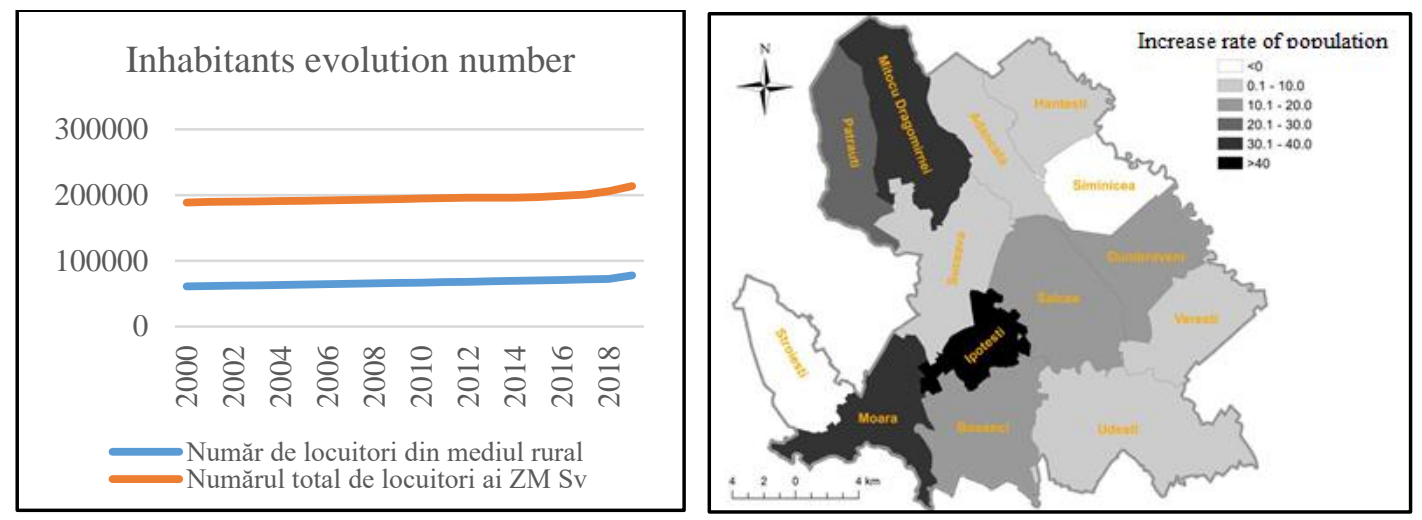

Figure 3. The evolution of inhabitants number

Therefore, in the first village category, which had an involution in terms of inhabitants' numbers, are Stroieşti and Siminicea. The situation of the two villages located in the metropolitan area of Suceava is similar, both of which registered a population decline in 2019, compared to 2000, of about $-4 \%$ (Stroieşti - -4\%; Siminicea - $-4.2 \%$ ), while being the territorial administrative units with the lowest number of inhabitants. As can be seen in the graph, in Stroieşti, in the last 20 years, the decrease in the number has become apparent since 2003, when it followed a downward course by 2019, with a slight increase in 2015. Siminicea, on the other hand, has experienced oscillations in the value of inhabitants' numbers during the analyzed period, according to which this demographic 
indicator has experienced a decrease since 2006, with short increasing periods of the inhabitants' number.

The demographic indicator of the utmost importance in the evolutionary contouring of a population, the birth rate is one of the two input factors (along with immigration) within a demographic system. In the retrospective analysis of the birth rate in recent years (2013 -2017) at the level of rural settlements in the metropolitan area of Suceava, it was found that the average value of this indicator is positive, $2.3 \%$. The highest values of the rural birth rate in the analyzed metropolitan area are specific to the Pătrăuţi (19.2 \%o), Bosanci $(16 \%)$.) and Mitocu Dragomirnei (15.6\%o).).The main factor that has caused a greater number of births in these villages is the defining demographic behavior of the Romani population, which is more within them. Adâncata, Stroieşti, and Siminicea have the lowest birth rate values of the analyzed period.

The mortality rate has high values in the Siminicea, Udeşti, and Stroieşti, where the share of the elderly population is higher. The lowest values of this indicator are specific Pătrăuţi, Ipoteşti, and Bosanci. As seen in the table 1 the territorial administrative units with a negative natural balance are Siminicea, Stroieşti, Adâncata, Udeşti, Hănţeşti. The increase in the inhabitants' number between 2013 and 2017, naturally characterizes Pătrăuţi, Bosanci Ipoteşti, Mitocu Dragomirnei, Dumbrăveni, Moara, and Vereşti. If we follow punctually the evolution of the indicators of natural dynamics in the analyzed five years, Adâncata, Siminicea, Stroieşti, Udeşti, and partly Hănțeşti where the mortality rate is higher than the birth rate.

Table 2. Natural and migratory dynamic

\begin{tabular}{|c|c|c|c|c|c|c|}
\hline T.A.U & $\begin{array}{c}\text { Birth rate } \\
(\%)\end{array}$ & $\begin{array}{c}\text { Mortality } \\
\text { rate (\%) }\end{array}$ & $\begin{array}{c}\text { Natural } \\
\text { balance } \\
(\%)\end{array}$ & $\begin{array}{c}\text { Arrivals (ext. } \\
\text { migr. ind - } \\
(\%)\end{array}$ & $\begin{array}{c}\text { Departures } \\
\text { (ext migr. } \\
\text { incl..-(\%) }\end{array}$ & $\begin{array}{c}\text { Migratory } \\
\text { balance (\%o) }\end{array}$ \\
\hline Siminicea & 9.1 & 16.1 & $\mathbf{- 6 . 9}$ & 11.2 & 11.7 & $\mathbf{- 0 . 5}$ \\
\hline Stroiești & 9.0 & 13.8 & $\mathbf{- 4 . 8}$ & 16.0 & 11.7 & $\mathbf{4 . 2}$ \\
\hline Adâncata & 9.0 & 13.2 & $\mathbf{- 4 . 1}$ & 19.4 & 14.3 & $\mathbf{5 . 0}$ \\
\hline Udești & 11.5 & 14.1 & $\mathbf{- 2 . 6}$ & 17.6 & 10.1 & $\mathbf{7 . 5}$ \\
\hline Hăntești & 10.0 & 11.1 & $\mathbf{- 1 . 1}$ & 15.5 & 12.2 & $\mathbf{3 . 3}$ \\
\hline Verești & 12.7 & 9.7 & $\mathbf{3 . 0}$ & 10.9 & 13.7 & $\mathbf{- 2 . 8}$ \\
\hline Moara & 13.0 & 9.9 & $\mathbf{3 . 1}$ & 34.0 & 13.2 & $\mathbf{2 0 . 8}$ \\
\hline Dumbrăveni & 14.8 & 10.0 & $\mathbf{4 . 7}$ & 15.3 & 12.5 & $\mathbf{2 . 7}$ \\
\hline $\begin{array}{c}\text { Mitocu } \\
\text { Dragomirnei }\end{array}$ & 15.6 & 9.5 & $\mathbf{6 . 1}$ & 24.9 & 14.0 & $\mathbf{1 0 . 9}$ \\
\hline Ipotești & 14.5 & 8.2 & $\mathbf{6 . 3}$ & 40.5 & 10.5 & $\mathbf{3 0 . 0}$ \\
\hline Bosanci & 16.0 & 8.8 & $\mathbf{7 . 3}$ & 11.8 & 11.5 & $\mathbf{0 . 4}$ \\
\hline Pătrăuți & 19.2 & 8.0 & $\mathbf{1 1 . 1}$ & 15.8 & 11.8 & $\mathbf{4 . 0}$ \\
\hline Suceava & 11.2 & 7.3 & $\mathbf{3 . 9}$ & 26.1 & 21.7 & $\mathbf{4 . 4}$ \\
\hline Salcea & 14.2 & 9.5 & $\mathbf{4 . 8}$ & 18.5 & 12.7 & $\mathbf{5 . 8}$ \\
\hline $\begin{array}{c}\text { Zona } \\
\text { Metropolitană }\end{array}$ & 12.9 & 10.6 & $\mathbf{2 . 3}$ & 19.8 & 13.0 & $\mathbf{6 . 8}$ \\
\hline Suceava & & & & & & \\
\hline
\end{tabular}

The territorial mobility of the population offers conclusive indications on the level of the urban and residential development of the rural territorial administrative units in the Metropolitan Area of Suceava. Following the analysis it was found that in the immediate vicinity of Suceava, in Ipotesti and Moara the migratory balance values, for the mentioned 
period, are very high, $30 \%$ and $20 \%$. The lowest values of the migratory balance were registered in Verești and Siminicea, the values were negative, $-2.8 \%$, respectively -0.5 $\%$.

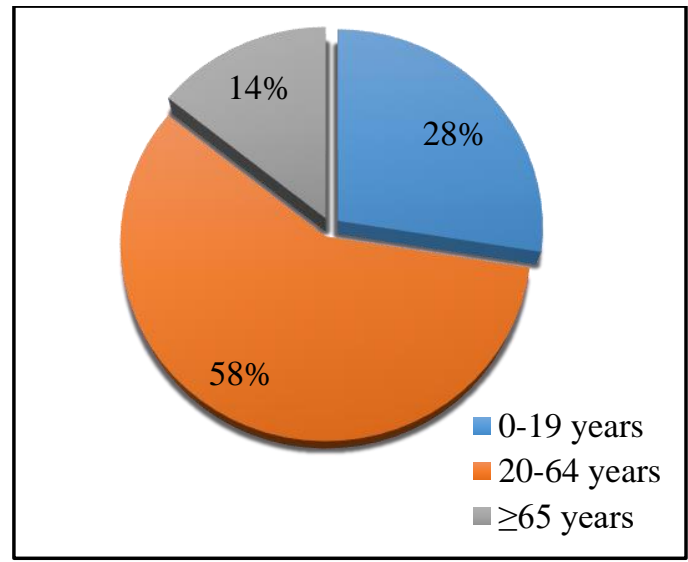

Figure 4. The age structure rate of population in the rural area of metropiltan area of Suceava

The structure of the population by age groups (figure 4) reflects the qualitative characteristics of the population with major implications in socio-economic activities. At the level of the rural settlements of the integrated villages in the metropolitan area of Suceava, during the analyzed period, the situation of the population share by age groups reveals a percentage of $28 \%$ of young population, a share of $58 \%$ of the adult population and a percentage of $14 \%$ of the older population. Compared with the urban population of the metropolitan area, there are a number of inequalities, such as a higher share of the young population in the rural population compared to the urban population, the difference being $4 \%$.

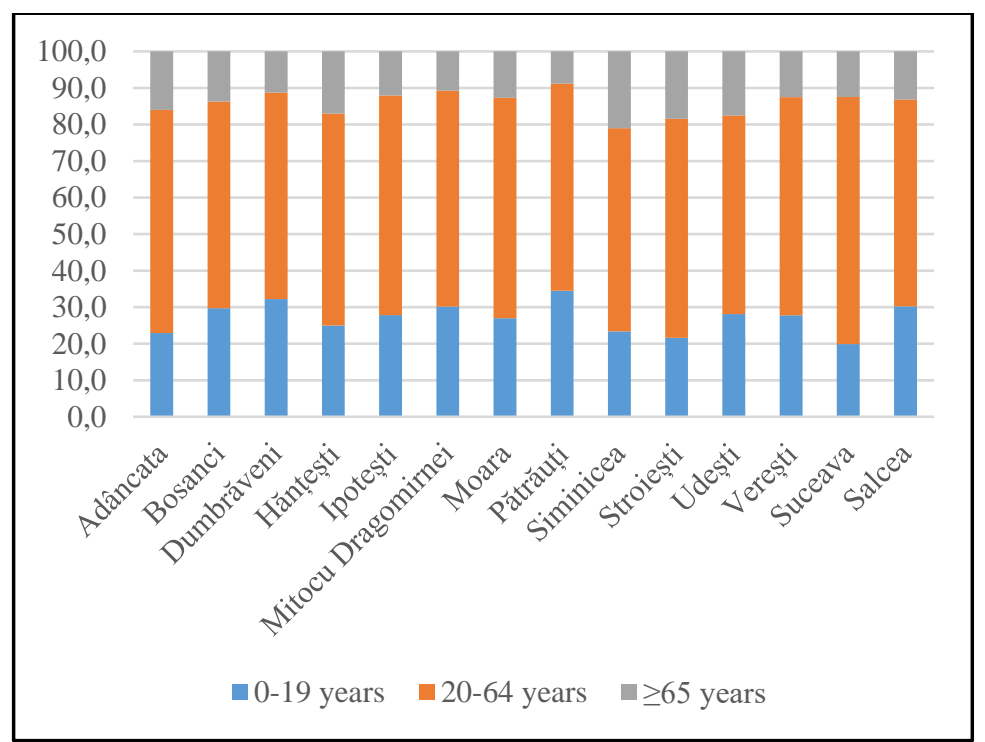

Figure 4. The age group structure of population

One reason for this is the migration of the adult and young population in certain villages around the city in recent years due to the accessibility of purchasing a living space, which maintains a high birth rate. Regarding the percentage of the population over the age of 65 , in rural settlements, a higher value is observed by two percent, while the adult population is higher in the case of urban settlements. 
At a particular level, one can observe very well the differences regarding the weight of the major age groups by highlighting within this way of population structure the demographic factors specific to each settlement (figure 4). For example, the high birth rate specific in Pătrăuți generates the highest share of the young population from the rural territorial administrative units in the metropolitan area of Suceava (34.5\%). High values of the population up to 20 years of age are also characteristic to Dumbrăveni, Mitocu Dragomirnei or Bosanci, where values close to $30 \%$ have been registered. Stroiești, Adâncata, and Siminicea registered values of less than $24 \%$ during the analyzed period. Undoubtedly, the causes that have determined the low values of the young population in the mentioned villages are those that explain, at the same time a high percentage of the elderly population. Poor technical-urban equipment and a lower level of living conditions are the main causes that are found in the shares of over $18 \%$ of persons 65 and over 65 in Siminicea and Stroiești. Aspects related to the progressive demographic behavior of the population of Pătrăuți, Mitocu Dragomirnei, and Dumbrăveni, either the favorability given by the easier accessibility to Suceava of the population or the degree of utilitarian equipping of the space in Ipotești and Moara generated a relatively lower share of the elderly population.

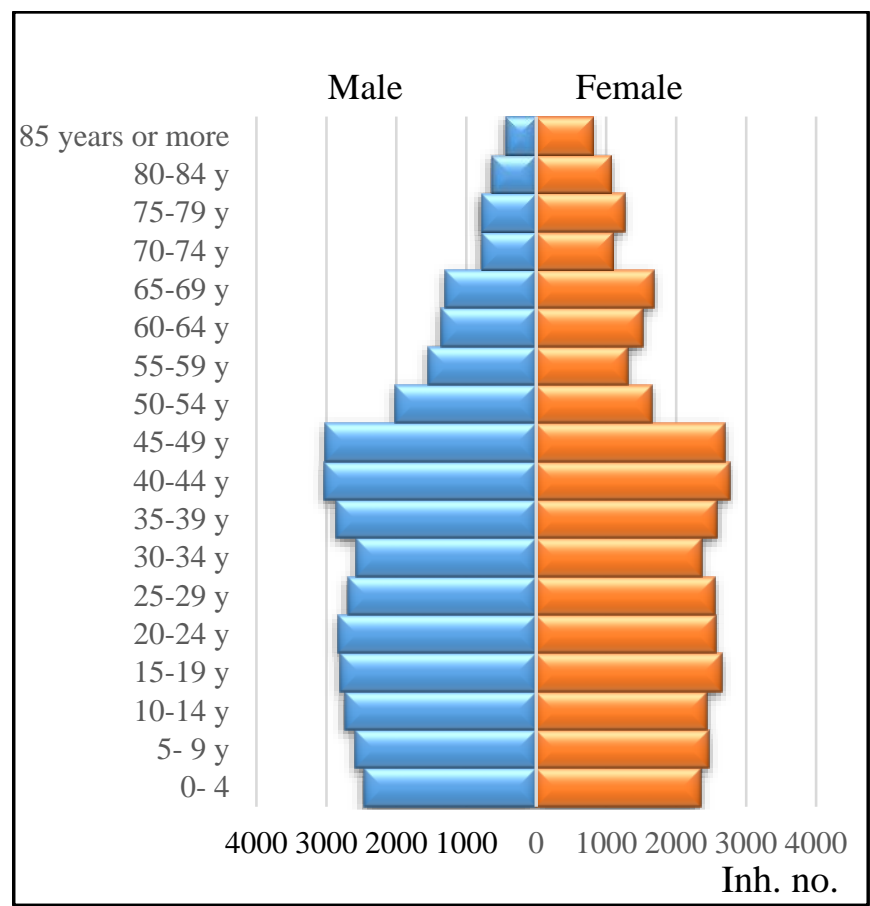

Figure 5. The population pyramid in the rural area of metropiltan area of Suceava

The representative age pyramid for the rural population of the metropolitan area of Suceava (figure 5) defines a population with a slight regressive tendency since its base is showing a slight decrease in the birth rate. Compared to the age pyramid the urban settlements in the metropolitan area of Suceava, it is observed, however, that the rural area has a higher population base. 


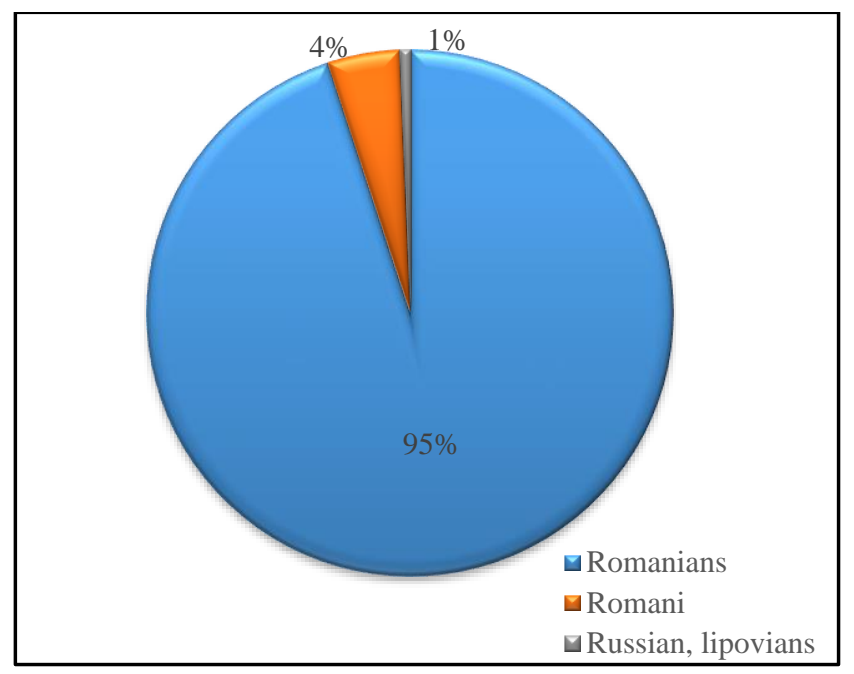

Figure 6. The ethinc structure share of population in the rural area of metropiltan area of Suceava

At the level of the territorial administrative units in the rural area, it was found within the realized analysis that there is some differentiation regarding the type of population according to the pyramid's type, ages, and sexes. Villages with a regressive population are Adancata, Hănțești, Siminicea, Stroiești or Udești. Corollary, the bell-type pyramid, in which the population has a tendency to stagnation, characterizes Bosanci, Dumbrăveni, Mitocu Dragomirnei, Moara, and Pătrăuţi. A distinct situation is that of Ipotești, in which the age pyramid has a form of an urn, the characteristic of the population being that of rejuvenation.

Table 2. The ethnic structure share of population

\begin{tabular}{|c|c|c|c|c|c|c|c|c|}
\hline & 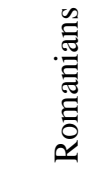 & 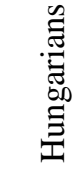 & 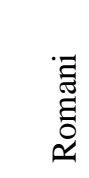 & 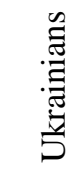 & ఏ્త్ర & 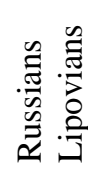 & $\begin{array}{l}\overline{0} \\
\frac{0}{0} \\
0\end{array}$ & 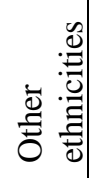 \\
\hline Adâncata & 98,83 & 0,00 & 1,12 & 0,00 & 0,00 & 0,00 & 0,00 & 0,00 \\
\hline Bosanci & 96,78 & 0,00 & 3,12 & 0,05 & 0,00 & 0,00 & 0,00 & 0,00 \\
\hline Dumbrăveni & 99,59 & 0,00 & 0,39 & 0,00 & 0,00 & 0,00 & 0,00 & 0,00 \\
\hline Hănțești & 99,97 & 0,00 & 0,00 & 0,00 & 0,00 & 0,00 & 0,00 & 0,00 \\
\hline Ipotești & 99,78 & 0,05 & 0,00 & 0,00 & 0,00 & 0,05 & 0,00 & 0,07 \\
\hline \multicolumn{9}{|l|}{ Mitocu } \\
\hline Dragomirnei & 82,53 & 0,00 & 10,02 & 0,00 & 0,00 & 7,45 & 0,00 & 0,00 \\
\hline Moara & 96,56 & 0,00 & 0,00 & 0,00 & 0,00 & 0,00 & 3,37 & 0,00 \\
\hline Pătrăuţi & 77,97 & 0,00 & 21,91 & 0,00 & 0,00 & 0,00 & 0,00 & 0,11 \\
\hline Siminicea & 99,66 & 0,00 & 0,30 & 0,00 & 0,00 & 0,00 & 0,00 & 0,00 \\
\hline Stroiești & 98,92 & 0,00 & 1,08 & 0,00 & 0,00 & 0,00 & 0,00 & 0,00 \\
\hline Udești & 95,77 & 0,00 & 4,20 & 0,00 & 0,00 & 0,00 & 0,00 & 0,00 \\
\hline Verești & 89,21 & 0,00 & 10,76 & 0,00 & 0,00 & 0,00 & 0,00 & 0,00 \\
\hline Suceava & 98,31 & 0,05 & 0,68 & 0,25 & 0,18 & 0,11 & 0,13 & 0,28 \\
\hline Salcea & 95,01 & 0,03 & 4,74 & 0,05 & 0,13 & 0,00 & 0,00 & 0,00 \\
\hline
\end{tabular}

From an ethnic point of view (figure 6), in the rural area of the metropolitan area of Suceava, one can speak of homogeneity, since the Romanian ethnic 
population occupies $95 \%$ of the total population. Of the two existing minorities in the analyzed area, the Romani population has a higher percentage, of about $4 \%$, while the Lipovan Russians are present in only $1 \%$.

Regarding the territorial administrative units, it was found that there are rural settlements consisting entirely of Romanian ethnic population, which are Siminicea, Hănțești, and Dumbrăveni. The Romani population has the highest values in Pătrăuţi, where more than $20 \%$ of the inhabitants belong to this ethnic group. Significant values are also characteristic to Verești or Mitocu Dragomirnei where their share of the total population exceeds $10 \%$.

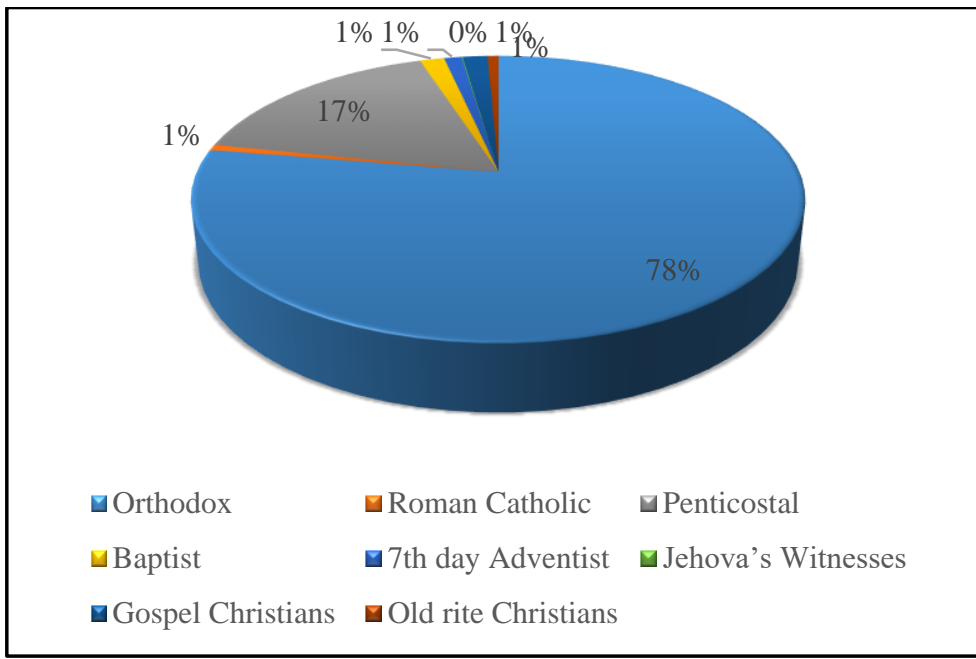

Figure 7. The confessional structure share of population in the rural area of metropiltan area of Suceava

Distinct situations are observed in Moara, where there is a 3\% percentage of Polish ethnicities and Mitocu Dragomirnei, where the weight of over 7\% of Polish inhabitants is noted. The shades of ethnic diversity that exist at the level of the mentioned localities can be a beneficial factor in the integrated development of the metropolitan area of Suceava.

Table 3. The confessional structure rate of population

\begin{tabular}{|c|c|c|c|c|c|c|c|c|}
\hline & 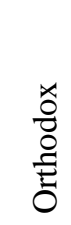 & 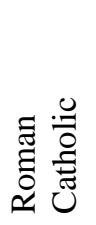 & 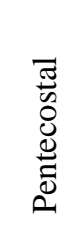 & 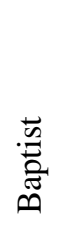 & 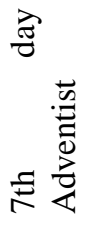 & 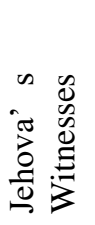 & 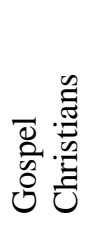 & 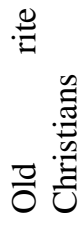 \\
\hline Adâncata & 95,2 & 0,0 & 4,4 & 0,0 & 0,2 & 0,0 & 0,1 & 0,0 \\
\hline Bosanci & 74,4 & 0,0 & 22,6 & 2,3 & 0,2 & 0,0 & 0,1 & 0,2 \\
\hline Dumbrăveni & 62,3 & 0,1 & 33,0 & 0,3 & 2,7 & 0,0 & 1,6 & 0,0 \\
\hline Hănțești & 88,5 & 0,0 & 11,1 & 0,0 & 0,3 & 0,0 & 0,0 & 0,0 \\
\hline $\begin{array}{l}\text { Ipotești } \\
\text { Mitocu }\end{array}$ & 65,3 & 0,5 & 23,3 & 9,4 & 0,1 & 0,1 & 1,1 & 0,1 \\
\hline Dragomirnei & 69,5 & 0,1 & 22,0 & 0,0 & 0,6 & 0,0 & 0,0 & 7,8 \\
\hline Moara & 82,8 & 6,9 & 9,3 & 0,4 & 0,2 & 0,0 & 0,3 & 0,0 \\
\hline Pătrăuți & 51,1 & 0,2 & 38,9 & 3,6 & 5,8 & 0,0 & 0,1 & 0,3 \\
\hline Siminicea & 94,5 & 0,0 & 4,3 & 0,9 & 0,4 & 0,0 & 0,0 & 0,0 \\
\hline Stroiești & 96,7 & 0,0 & 1,5 & 0,0 & 1,0 & 0,6 & 0,1 & 0,0 \\
\hline Udești & 71,1 & 0,0 & 18,4 & 0,1 & 1,4 & 0,0 & 8,8 & 0,0 \\
\hline Verești & 79,4 & 0,1 & 12,0 & 1,4 & 0,3 & 0,0 & 6,8 & 0,0 \\
\hline Suceava & 91,3 & 1,7 & 4,5 & 0,8 & 0,3 & 0,1 & 0,8 & 0,3 \\
\hline Salcea & 68,7 & 0,2 & 20,6 & 1,0 & 0,5 & 0,1 & 8,9 & 0,1 \\
\hline
\end{tabular}


Regarding the religious view, about $78 \%$ of the total population belongs to the Orthodox cult (figure 7). In descending order, the Pentecostal population has a share of $17 \%$, the rest of the confessions being represented by low percentages, of about $1 \%$.

The confessional structure of the population is a determining factor of the demographic conduct within a population. In general, Christian religions encourage birth, but there are differences in the relationship between birth rate and membership in one cult or another. For example, in the localities of the metropolitan area of Suceava (table 3), it is observed that the birth rate is higher, where there is a larger population belonging to the Pentecostal cult.

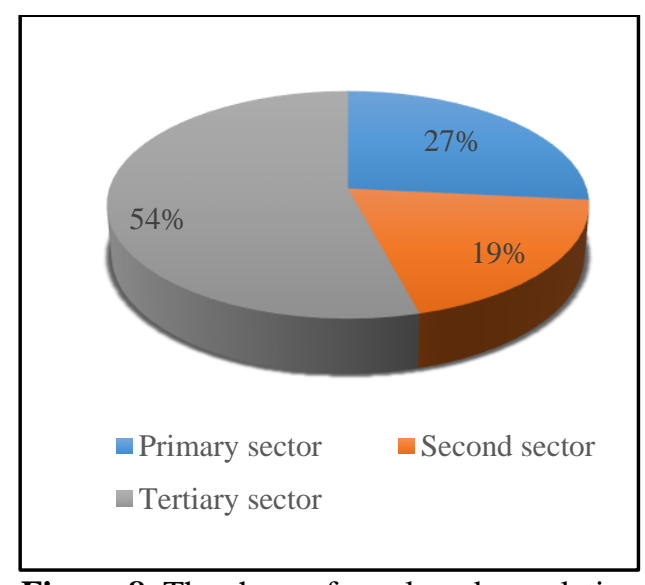

Figure 8. The share of employed population

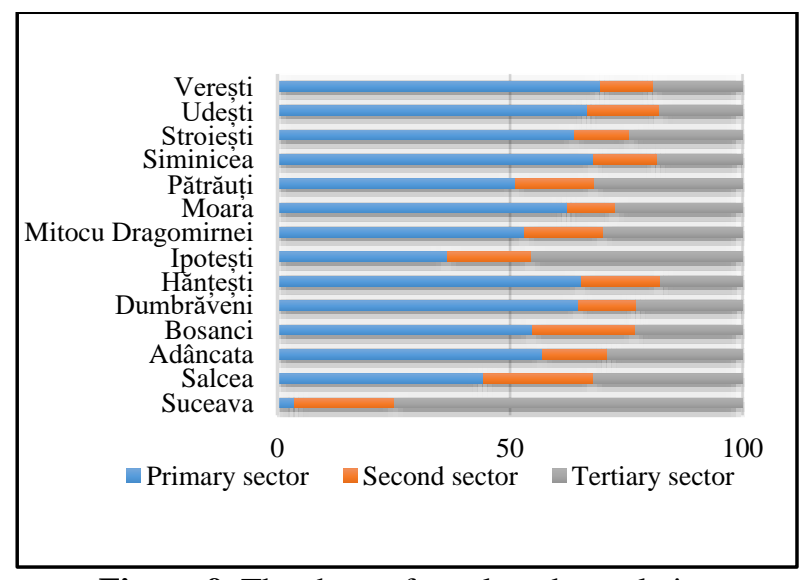

Figure 9. The share of employed population

Such situations characterize Pătrăuți and Dumbrăveni where the followers of the Pentecostal cult exceed $30 \%$ of the total population. High values of the Pentecostal population are also found in Ipotesti, Bosanci or Mitocu Dragomirnei, where the values exceed $20 \%$ of the total population. Moara, which has a significant percentage of Polish ethnicities, is the one with the highest value of the Roman Catholic population, which is demonstrated by the percentage of about $7 \%$.

Regarding the occupational structure of the population, in the rural settlements around Suceava (figure 8), $54 \%$ of the employed population carry out their activities in the primary sector. The service sector is represented by $27 \%$ of the total population, and 19 $\%$ of the inhabitants active in the labor market are employed in the secondary sector.

The territorial differentiation within the metropolitan area of Suceava, are visible, especially, in Ipotești, in which there is the lowest percentage of the population employed in agriculture. The primary sector is the one in which about $50 \%$ of the total active population in Pătrăuţi and Mitocu Dragomirnei, while in Verești, Siminicea, and Udești, the share of the population is over $65 \%$. The secondary sector is poorly represented at the level of rural settlements in the analyzed metropolitan area (figure 9).

The cause is supported by the regional character of the entire region of which the metropolitan area of Suceava is part, where the level of development of the secondary sector is low. Regarding the services sector, Ipotești is the one with the largest number of inhabitants employed in this economic sector, the share is about $45 \%$. The areas in which they operate are diverse. Proximity to Suceava is the main factor that influenced the occupational structure of the population. Of those employed in the services sector, the highest share is specific to those active in the field of trade (46\%), followed by those employed in the fields of public administration, health and education, in each of them activating about $15 \%$. High values of the population employed in the tertiary sector also 
characterize Pătrăuţi and Mitocu Dragomirnei, where about $30 \%$ of the actively employed persons carry out their activities mainly in the commercial field.

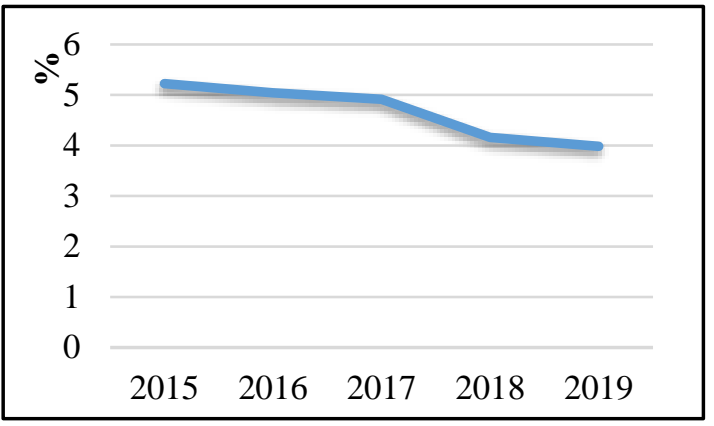

Figure 10. The unemployment rate in the rural area of metropiltan area of Suceava

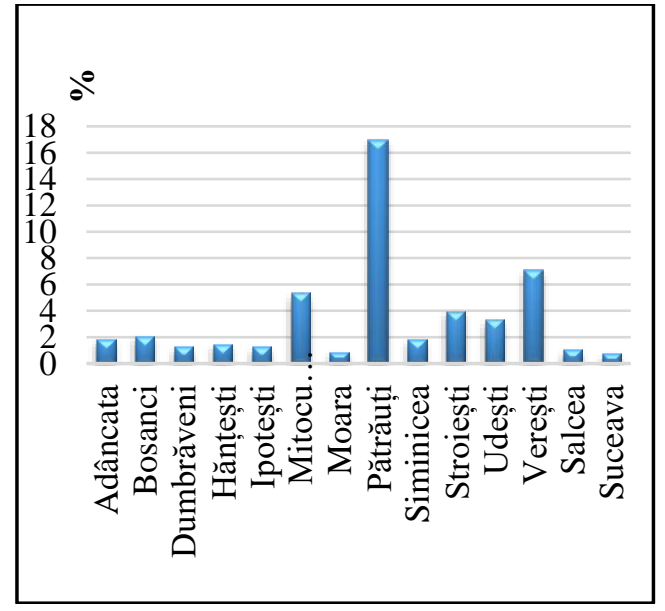

Figure 11. The unemployment rate

In the last five years analyzed, the unemployment rate has followed a downward trend in the analyzed rural settlements, decreasing from 5.2\% in 2015 to $3.9 \%$ in 2019 (figure 10). The last year under review emphasized that the high unemployment rate belongs to Pătrăuți, its value is $17 \%$. With a difference of about $10 \%$, Verești, and values above the rural area average, are registered in Mitocu Dragomirnei and Stroiești (figure 11). The lack of jobs in these areas, the lack of professional training, but also the high share of the Romani population within them, are the main causes for the high values recorded. The lowest values of the unemployment rate characterize the most developed localities from the point of view of living conditions and the level of development, namely, Ipotesti and Moara, the value is about $1 \%$.

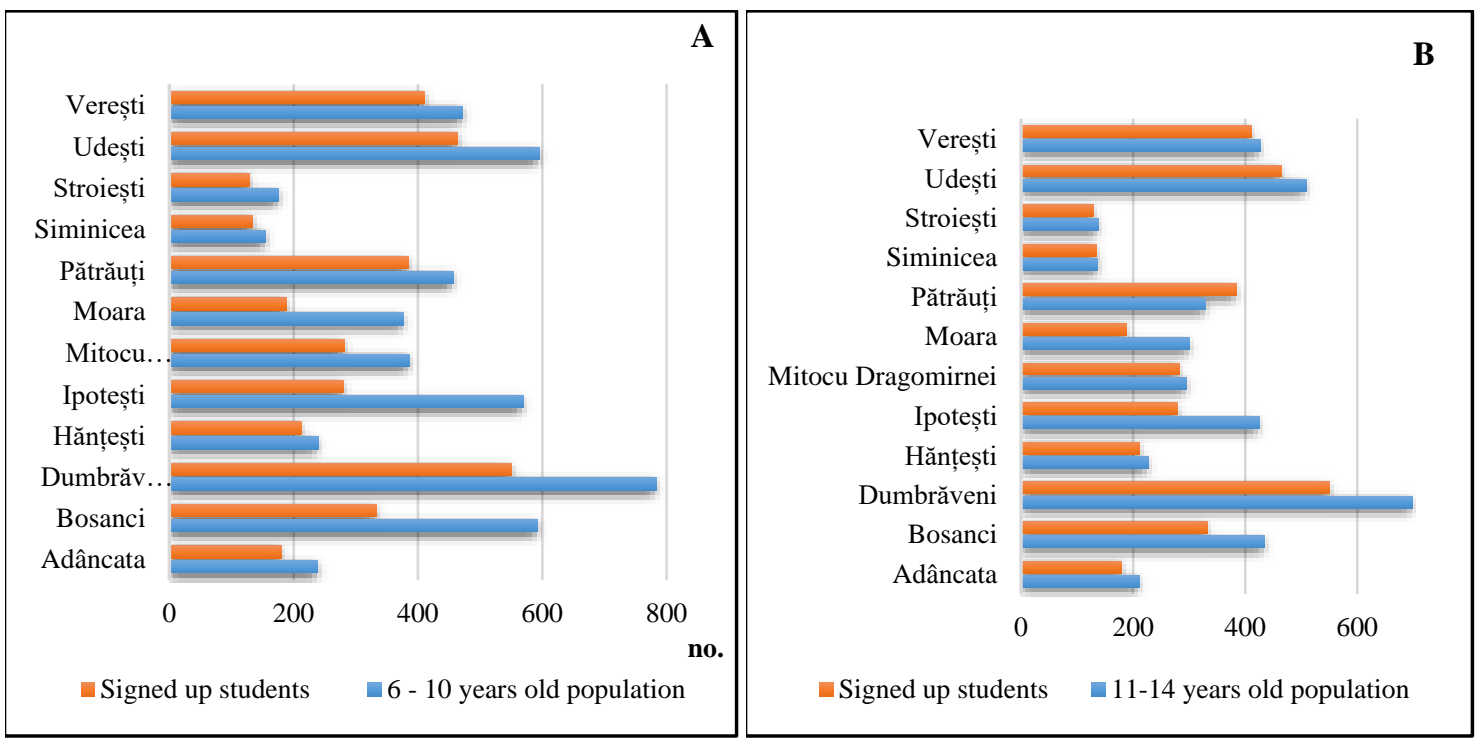

Figure 12. The relationship between the school age population and the students enrolled in primary education (A) and in gymnasium education (B)

From an educational point of view, in the rural area can be accessed pre-school, primary, secondary and professional levels, high school education, belonging to Suceava. One of 
the characteristics of the school population in the metropolitan rural area is the school migration. To highlight this fact, we analyzed the number of children, of school-age compared to the number of students enrolled in primary and secondary education levels, in 2018 (the last year in which we have data). Following the two graphs it can be observed that in Udești, Moara, Ipotești, Dumbrăveni, and Bosanci, the school migration is very high. At the level of primary education, in these localities, the share of the population following the studies near home ranges from 50-60\%. The same tendency also appears at the level of secondary education, which negatively influences the educational structure of the population (figure 12).

\section{CONCLUSION}

Following the analysis of the main demographic indicators, the overall picture of the rural population's potential in the metropolitan area of Suceava was outlined. One of the favorable demographic elements is the upward trend that characterizes the evolution of the inhabitants' number. The phenomenon of suburbanization has led to an increase in the number of inhabitants in Ipotești, Mitocu Dragomireni, and Moara, where the population growth rate has exceeded $30 \%$. Regarding the dynamics of the population, overall, the natural balance is a positive one, which in perspective, under the conditions of a coherent economic-social development, can constitute the human resource with access to the opportunity of qualitative increase of the level of preparation. The outbreaks of population growth based on the natural dynamics of the metropolitan area are Verești, Mitocu Dragomirnei, Moara, Ipotești, Bosanci, and Pătrăuţi. Also, there are localities where the share of the young population is high (Dumbrăveni, Mitocu Dragomirnei, and Pătrăuţi), where the share is over $30 \%$, which reinforces the fact that in the analyzed area, there is a high potential of the workforce. From an ethical point of view, the rural population presents homogeneity, the representative minority being that of the Romani population, having a higher concentration in Pătrăuți. Some heterogeneity was found in the confessional structure of the population, in the rural area, coexisting in all the localities, Orthodox and Pentecostal.

The elements that can negatively influence the process of integrated development of the metropolitan area, from the rural area, consist in the decrease of the inhabitants' number in Stroiești and Siminicea, intensely affected by the demographic aging process, the migration of the population within them, in the absence of the places of work, either in the urban area of the metropolitan area, or outside it, or the high share of the Romani population, in Pătrăuți e, which may constitute a social imbalance. The precarious membership of the Romani population in the social-economic life, the follow-up of the compulsory education, the high unemployment rate and the integration on the labor market can restrain, from the demographic point of view, the development of the metropolitan area of Suceava.

\section{REFERENCES}

[1] Cândea Melinda, Bran Florina, Cimpoeru Irina, The organization, the planning and the sustainable development of the geographical space, Editura Universitară, București, 2006, pp 330

[2] Ianoș Ioan, Territorial systems, Editura Tehnică, București, 2000, pp 27-28

[3] Săgeată Radu, Galați - Brăila metropolitan zone. Proposal, in Comunicări de Geografie, XI, Edit. Universităţii Bucureşti, 2007, pp 443-450

Secţiunea a IV-a - Reţeaua de localităţi, 351, Bucureşti 
[4] Legea privind aprobarea Planului de amenajare a teritoriului naţionalSecţiunea a IV-a Rețeaua de localităţi, 351, Bucureşti (2001).

[5] Statistical Yearbook of Suceava county 2000 - 2019, National Institut of Statistics București, (tempo - online) 